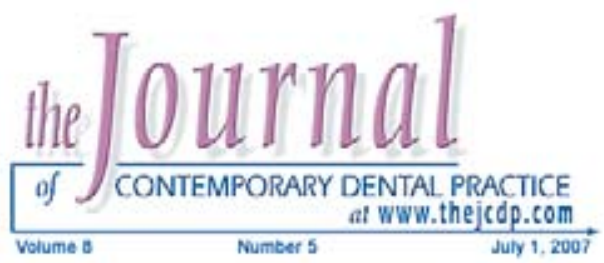

\title{
Three-dimensional Surface Profile Analysis of Different Types of Flowable Restorative Resins Following Different Finishing Protocols
}

\section{A. Rüya Yazici, DDS, PhD; Ali Mütü, DMD, MS; Gerard Kugel, DMD, MS, PhD}

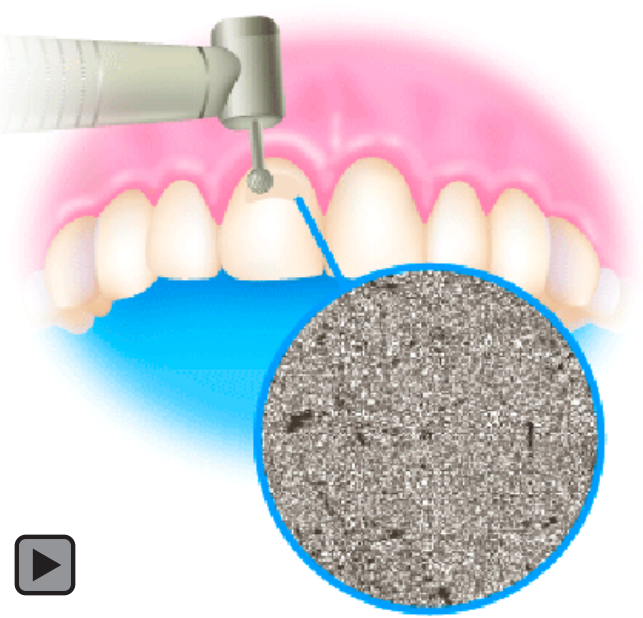

Abstract

Aim: The aim of this study was to investigate the surface roughness of different types of flowable restorative resins and compare the effectiveness of diamond finishing burs followed by aluminum oxide discs with aluminum oxide discs alone in producing smooth surfaces.

Methods and Materials: Twenty-four specimens $(10 \mathrm{~mm} X 2 \mathrm{~mm}$ ) for each flowable resin (flowable microhybrid composite, flowable liquid microhybrid composite, flowable compomer, and flowable ormocer) were fabricated in an acrylic mold and randomly assigned to three groups. In group I samples were left undisturbed after the removal of a Mylar strip (control). In group II samples were polished with diamond finishing burs, followed by aluminum oxide discs. In group III samples were finished with only aluminum oxide discs. The mean surface roughness $(\mathrm{Ra}, \mu \mathrm{m})$ was determined with 3-D non-contact interferometry. Data were subjected to one way analysis of variance (ANOVA), and post hoc comparison was accomplished using Tukey's HSD.

Results: Although significant differences in surface roughness (Ra) values were observed among the materials using a Mylar strip (control), no significant differences between restorative materials were found when all finishing/polishing methods were combined. For all flowable restorative resins tested, the Mylar strip produced surfaces smoother than those produced by a diamond finishing bur followed by a disc or by using discs alone. Surface roughness values were statistically similar for a diamond finishing bur followed by a disc and for disc treated surfaces within each material except for Dyract Flow, a flowable compomer.

(c) Seer Publishing 
Conclusion: Although the surface roughness of flowable restorative resins differs among the types, this difference can be overcome with different finishing/polishing methods.

Keywords: Flowable restorative resin, surface roughness, surface finishing

Citation: Yazici AR, Müftü A, Kugel G. Three-dimensional Surface Profile Analysis of Different Types of Flowable Restorative Resins Following Different Finishing Protocols. J Contemp Dent Pract 2007 July;(8)5:009-017.

\section{Introduction}

Recently introduced flowable restorative resins offer an additional choice of tooth-colored restorative materials. Flowable restorative resins are indicated for the restoration of minimally invasive preparations and especially for cervical Class $\mathrm{V}$ lesions due to their low viscosity and increased elasticity. Compared to microfilled resins, the filler loading of flowables are reduced resulting in an enhanced flow and a reduced elastic modulus. ${ }^{1}$ The reduced elastic modulus may provide the material with stress-absorbing ability, and improved flow is likely to facilitate adaptation. $^{2}$

Proper finishing and polishing of cervical restorations are important procedures that enhance esthetics, gingival health, periodontal integrity, and longevity of restored teeth. ${ }^{3,4}$ The smoothest surfaces are achieved when resin material is cured against Mylar strips. However, properly contoured restorations are seldom achieved without the need to remove excess material. $^{5}$

There are a variety of instruments to accomplish finishing and polishing, each producing different results for different composites. ${ }^{6,7}$ One of the most commonly performed procedures to remove excess includes finishing with diamond burs and polishing with aluminum discs. ${ }^{8,9}$ Diamond burs have a tendency to tear filler particles and leave irregularities on resin surfaces. However, finishing with aluminum discs has been reported to reduce these defects. ${ }^{10}$ On the other hand, Ferreira et al. ${ }^{11}$ have demonstrated a restoration free from marginal excess and with smooth surfaces can be achieved using a proper matrix, special care in the insertion of composite, and meticuluous technique to eliminate the need for finishing and polishing.

Several different types of composite resins have been the subject of surface evaluation. ${ }^{12-17}$

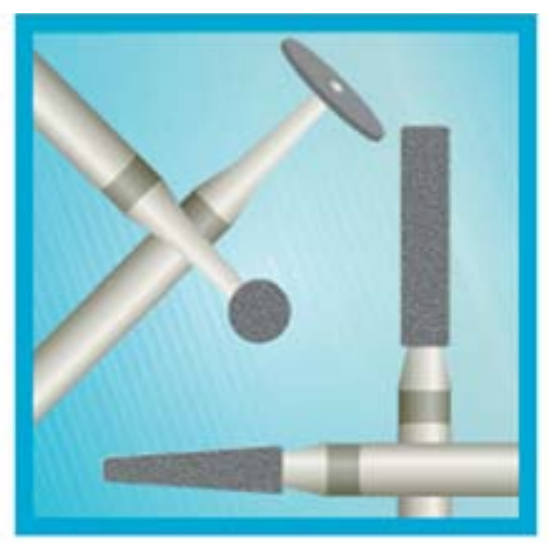

However, information is limited about the surface characteristics of flowable restorative resins in common use for cervical restorations. Because the size, shape, and volume of composite fillers affect surface morphology, one aim of this study was to evaluate surface roughness of different types of flowable restorative resins using the three-dimensional white-light interferometry. An additional aim was to compare the effectiveness of diamond finishing burs followed by aluminum oxide discs with aluminum oxide discs alone in producing a smooth surface on flowable restorative resins.

\section{Methods and Materials}

\section{Study Population}

Four different types of flowable restorative resins were selected for this study and are listed as follows (Table 1):

- Tetric Flow (Vivadent, Schaan, Liechtenstein), a flowable microhybrid composite.

- Esthet-X Flow (Dentsply, Caulk, Milford, $\mathrm{DE}, \mathrm{USA}$ ), a flowable liquid microhybrid composite.

- Dyract Flow (Dentsply, Konstanz, Germany), a flowable compomer.

- Admira Flow (Voco, Cuxhaven, Germany), a flowable ormocer. 
Table 1. Composition of flowable restorative resins.

\begin{tabular}{|c|c|c|c|c|}
\hline $\begin{array}{c}\text { Flowable } \\
\text { Restorative } \\
\text { Resin }\end{array}$ & Manufacturer & Composition & $\begin{array}{l}\text { Filler } \\
\text { Content } \\
(\% \text { vol) }\end{array}$ & $\begin{array}{l}\text { Particle } \\
\text { Size }(\mu \mathrm{m})\end{array}$ \\
\hline $\begin{array}{l}\text { Tetric Flow } \\
\text { D55349 }\end{array}$ & $\begin{array}{l}\text { Vivadent, } \\
\text { Schaan, } \\
\text { Liechtenstein }\end{array}$ & $\begin{array}{l}\text { Barium glass, ytterbium trifluoride, } \\
\text { Ba-Al-fluorosilicate glass, highly } \\
\text { dispersed silicon dioxide, spheroid } \\
\text { mixed oxide BisGMA, urethane } \\
\text { dimethacrylate, triethylene glycol } \\
\text { dimethacrylate }\end{array}$ & $\begin{array}{l}68.1 \mathrm{wt} \\
43.8 \mathrm{vol}\end{array}$ & $\begin{array}{c}0.7(0.04- \\
3.0)\end{array}$ \\
\hline $\begin{array}{l}\text { Esthet-X } \\
\text { Flow } \\
0210017\end{array}$ & $\begin{array}{l}\text { Dentsply,Caulk, } \\
\text { Milford, DE, } \\
\text { USA }\end{array}$ & $\begin{array}{l}\text { Barium fluoro alumino-boro silicate } \\
\text { glass, nanofiller silica Urethane } \\
\text { modified BisGMA adduct, } \\
\text { BisGMA, diluents }\end{array}$ & $61 w t, 53 v o l$ & $<0.02$ \\
\hline $\begin{array}{l}\text { Dyract Flow } \\
000801\end{array}$ & $\begin{array}{l}\text { Dentsply, } \\
\text { Konstanz, } \\
\text { Germany }\end{array}$ & $\begin{array}{l}\text { Strontium-alimino-fluoro-silicate } \\
\text { glass, ammonium salt of PENTA, } \\
\mathrm{N} \text {, N-dimethylaminoethyl } \\
\text { methacrylate, carboxylic acid } \\
\text { modified macromonomers, iron } \\
\text { pigments, titanium dioxide }\end{array}$ & $59 \mathrm{wt}, 43 \mathrm{vol}$ & 1.5 \\
\hline $\begin{array}{l}\text { Admira Flow } \\
21964\end{array}$ & $\begin{array}{l}\text { Voco, } \\
\text { Cuxhaven, } \\
\text { Germany }\end{array}$ & $\begin{array}{l}\text { Barium-aluminium-boro-silicate } \\
\text { glass, silicone dioxide ormocers, } \\
\text { BisGMA, urethan-dimethacrylat } \\
\text { (UDMA), triethylene-dimethacrylat } \\
\text { (TEDMA) }\end{array}$ & $\begin{array}{c}64 w t, 50.5 \\
\text { vol }\end{array}$ & $\begin{array}{c}0.7(0.04- \\
1.2)\end{array}$ \\
\hline
\end{tabular}

Plexiglass molds with disk-shaped specimen wells $(10 \mathrm{~mm} \times 2 \mathrm{~mm}$ ) were used to make the specimens. The restorative materials were placed in the molds and covered with a Mylar strip then compressed with a glass slide using hand pressure to extrude excess material. The samples were then light polymerized for 40 seconds using a Spectrum 800 curing light (Dentsply, Milford, DE, USA) with an output intensity, as assessed with a curing radiometer, of $>400 \mathrm{~mW} / \mathrm{cm}^{2}$. All specimen preparation, finishing, and polishing procedures were carried out by the same investigator in order to minimize variability.

Twenty-four specimens for each flowable resin were prepared and randomly assigned to three groups as follows (Table 2):

- Group I: Samples were left undisturbed after the removal of the Mylar strip (control).

- Group II: Samples were first polished with 24-40 $\mu \mathrm{m}$ and 15-30 $\mu \mathrm{m}$ grit finishing diamond burs (Brasseler, Savannah, GA, USA) followed by medium, fine, and ultra-fine aluminum oxide discs (Sof-Lex Pop-On, 3M Dental Products, St. Paul, MN, USA).
- Group III: Samples were finished only with aluminum oxide discs (Sof-Lex Pop-On, 3M Dental Products, St. Paul, MN, USA).

The Sof-Lex discs were changed after finishing and polishing each sample, whereas the diamond burs were changed after every two samples. All high-speed finishing burs were used with an air-water spray. Discs were used with a slow-speed handpiece using water as a coolant. All specimens were kept wet during finishing procedures and were stored in $37^{\circ} \mathrm{C}$ deionized water for 24 hours. They were then rinsed and dried to minimize any debris prior to surface roughness readings.

Specimen surfaces were analyzed with a Zygo New View 5000 3-D surface profiler (Zygo, Middlefield, CT, USA). The NewView 5000 is based on scanning white-light interferometry. This is a traditional technique in which a pattern of bright and dark lines (fringes) result from a difference in the optical paths between a reference and a sample beam. Incoming light is split inside an interferometer with one beam going to an internal reference surface and the 
Table 2. The finishing/polishing systems evaluated.

\begin{tabular}{|l|l|c|c|}
\hline & Manufacturer & Lot \# & Particle Size \\
\hline Finishing diamond & $\begin{array}{l}\text { Brasseler, Savannah, GA } \\
31419, \text { USA }\end{array}$ & Z5642 & $24-40 \mu \mathrm{m}$ \\
\hline Finishing diamond & $\begin{array}{l}\text { Brasseler, Savannah, GA } \\
31419, \text { USA }\end{array}$ & Z5214 & $15-30 \mu \mathrm{m}$ \\
\hline Discs & $\begin{array}{l}\text { Sof-Lex Pop-On, 3M Dental } \\
\text { Products St. Paul, MN } \\
55144, \text { USA }\end{array}$ & 1980 & Fine $(24 \mu \mathrm{m})$ \\
\hline
\end{tabular}

Table 3. Mean surface roughness ( $\mathrm{Ra}, \mu \mathrm{m})$ and standard deviation for flowable restorative resins and finishing/polishing systems evaluated.

\begin{tabular}{|l|c|c|c|}
\hline $\begin{array}{c}\text { Flowable Restorative } \\
\text { Resins }\end{array}$ & Mylar & Finishing Bur & Disc \\
\hline Tetric Flow & $0.044(0.24)$ & $0.18(0.27)$ & $0.17(0.18)$ \\
\hline Esthet-X Flow & $0.021(0.60)$ & $0.16(0.32)$ & $0.18(0.34)$ \\
\hline Dyract Flow & $0.043(0.11)$ & $0.12(0.33)$ & $0.17(0.43)$ \\
\hline Admira Flow & $0.030(0.12)$ & $0.16(0.40)$ & $0.14(0.43)$ \\
\hline
\end{tabular}

other to the sample. After reflection, the beams recombine inside the interferometer and undergo constructive and destructive interference, which produces the light and dark fringe patterns. A precision vertical scanning transducer and camera in the NewView 5000 together generate a three-dimensional interferogram of the surface. This interferogram is processed by a computer and transformed using frequency domain analysis which results in a quantitative non-contact 3-D image. $^{18}$

For this study, the surface roughness parameter (Ra: an arithmetic mean of the sum of roughness profile values) is considered to be most representative and was taken into account. One way analysis of variance (ANOVA) and Tukey's HSD test (alfa $=0.05)$ were used for statistical analysis.

\section{Results}

Means and standard deviations of surface roughness $(\mathrm{Ra}, \mu \mathrm{m})$ of flowable restorative resins and finishing/polishing systems evaluated in this study are presented in Table 3. One way ANOVA revealed a significant difference between restorative materials under the Mylar strip $(p<0.05)$. Although the smoothest surfaces were obtained under the Mylar strip (control) for all flowable restorative resins, significant differences in surface roughness were observed between
Esthet-X Flow and Tetric Flow and between Esthet-X Flow and Dyract Flow under the Mylar strip.

Finishing with diamond burs followed by discs (Group II) and only disc-treated samples (Group III) showed significantly higher surface roughness in contrast to the Mylar strip group $(p<0.05)$. However, no significant differences among restorative materials were found when all finishing/polishing methods were combined (p>0.05).

For all but Dyract Flow, using diamond finishing burs followed by aluminium discs resulted in a surface of similar roughness for all restorative materials to that obtained with aluminum discs alone ( $p>0.05)$. Samples of Dyract Flow treated initially with burs followed by discs showed lower Ra values compared to specimens treated with only discs $(p<0.05)$.

The 3-D surface profiler provides a filled and a oblique plot, both with a colorimetric evaluation. ${ }^{18}$ The histogram recorded for each area of each sample tested is characterized by counts (on the Y-axis) associated with a different surface level. A narrow histogram indicates a homogeneous area. ${ }^{18}$ Three dimensional oblique plots of the samples created by the Zygo surface profiler are presented in Figures 1 through 4. 



Figure 1. Zygo 3-D oblique plots of representative samples of Tetric Flow. A. Under a Mylar strip. B. Polished with diamond finishing burs, followed by finishing discs. C. Finished with only aluminum oxide discs.
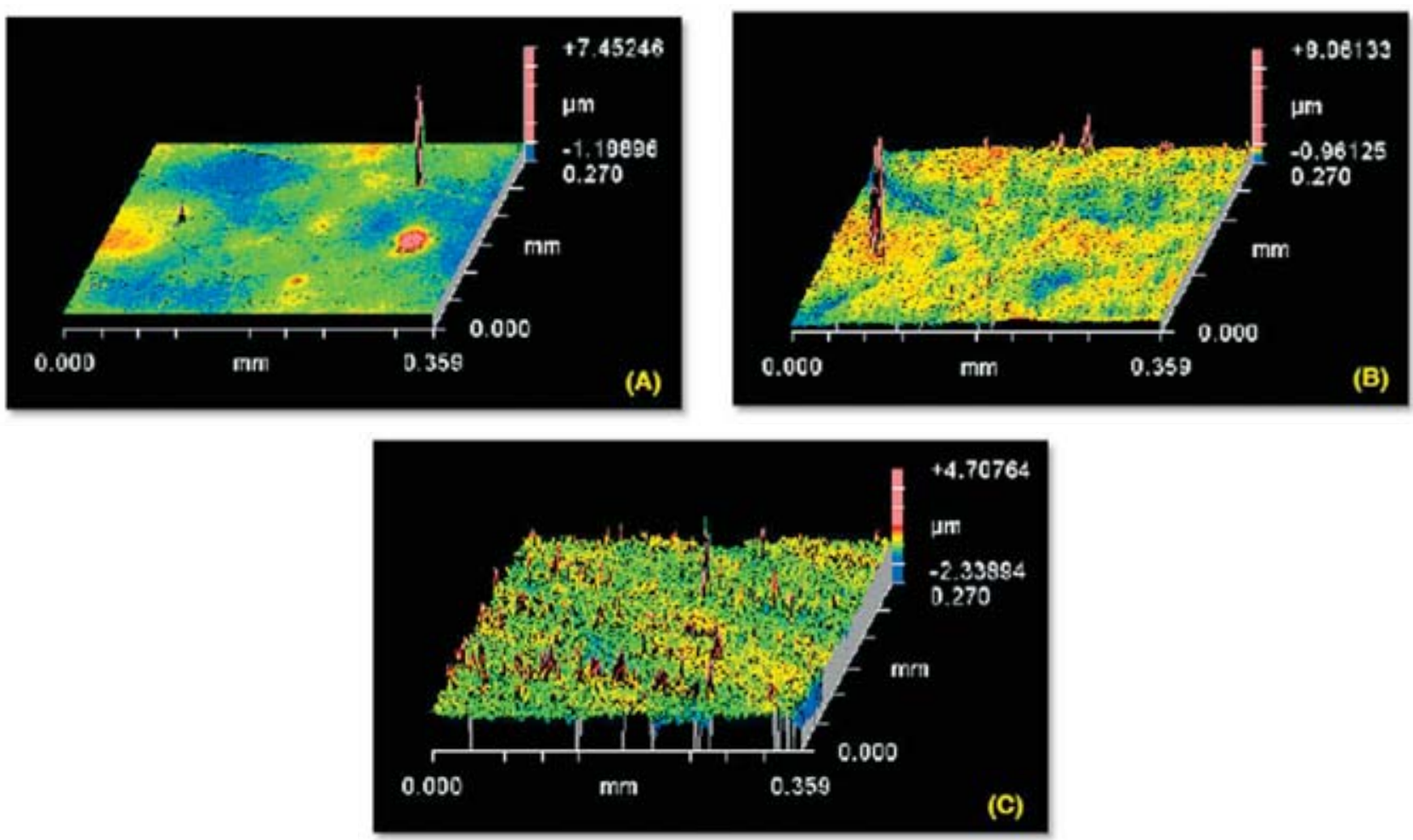

Figure 2. Zygo 3-D oblique plots of representative samples of Esthet-X Flow. A. Under a Mylar strip. B. Polished with diamond finishing burs, followed by finishing discs. C. Finished with only aluminum oxide discs. 



Figure 3. Zygo 3-D oblique plots pf representative samples of Dyract Flow. A. Under a Mylar strip. B. Polished with diamond finishing burs, followed by finishing discs. C. Finished with only aluminum oxide discs.
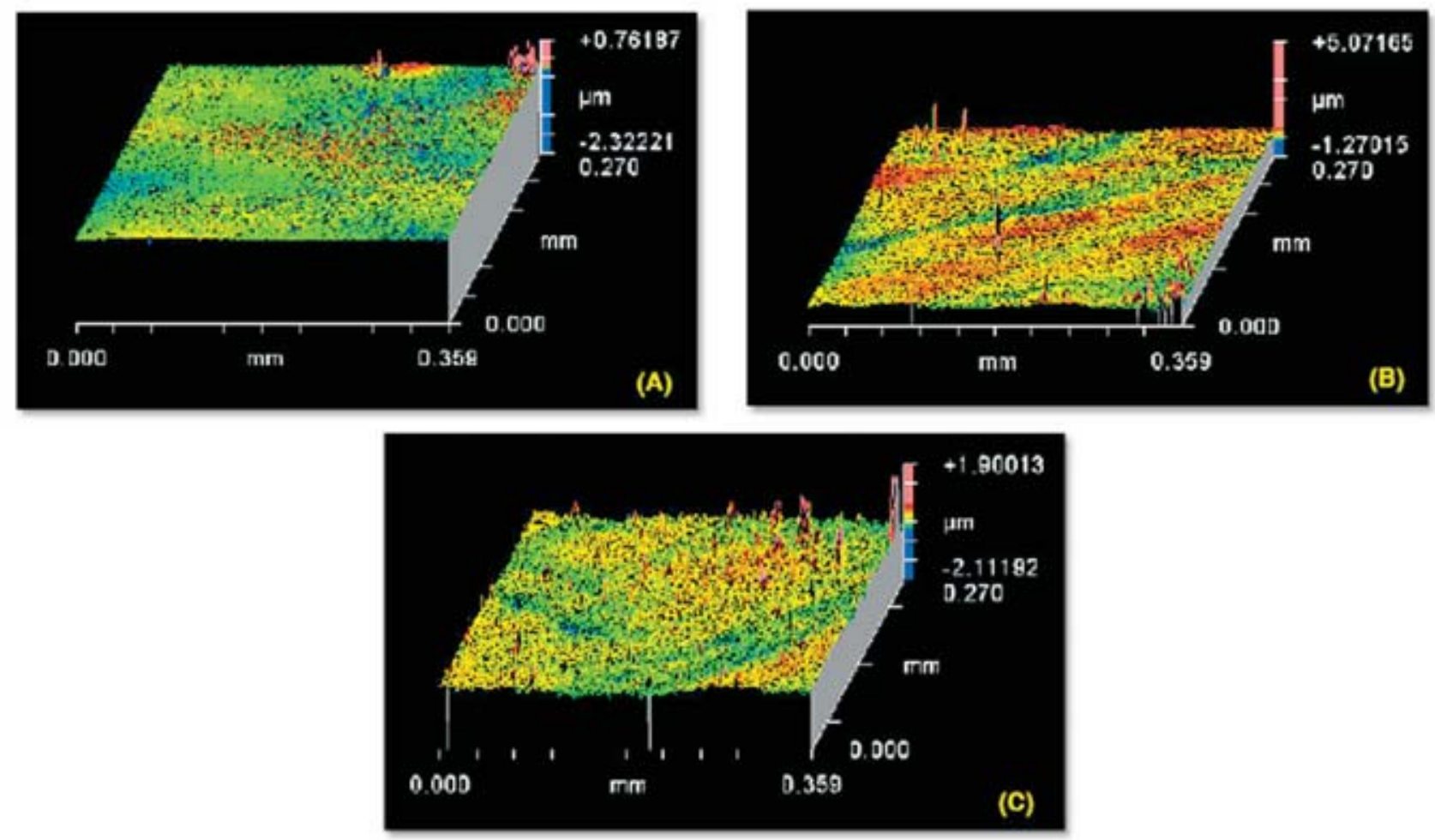

Figure 4. Zygo 3-D oblique plots of representative samples of Admira Flow. A. Under a Mylar strip. B. Polished with diamond finishing burs, followed by finishing discs. C. Finished with only aluminum oxide discs. 
Because the Zygo machine also provides surface images, qualitative analyses were performed without the need for scanning electron microscopy. The interferometry microphotographs of reperesentative samples of the different finishing/polishing techniques for each material are presented in Figures 5 through 8.

The interferometry microphotographs demonstrated the surfaces under the Mylar strip were homogeneous. The surfaces treated by finishing diamonds followed by discs and disc alone showed numerous grooves running parallel to the direction of rotating of the disc. Scratches were also observed on resins.

\section{Discussion}

Restorations in close approximation to gingival tissues require surface smoothness for optimal gingival health. Use of flowable restorative resins in cervical locations requires special attention to establish smooth surfaces in order to avoid plaque retention, surface discoloration, and gingival inflammation. Flowable restorative resins are available with a variety of filler types that affect both their handling characteristiscs and physical properties. In the present study no significant differences were observed in Ra values between unpolished specimens (against a mylar strip) of Dyract Flow, Tetric Flow, and Admira Flow. This may be due to the similarity in mean particle size of these three flowable resins. Filler particle size has a direct effect on the surface roughness of a ground, finished, or polished composite. ${ }^{19}$

The smoothest surface was produced in the Esthet-X samples, which also has the smallest particle sizes. Dyract Flow contains the largest filler particles of the restoratives examined and, therefore, has the roughest surface statistically different from Esthet-X Flow. Admira Flow, a flowable ormocer, has an average particle size of $0.7 \mu \mathrm{m}$ with a range of $0.04-1.2$. Although Admira Flow's particle size is similar to Tetric Flow, the surface roughness values were slightly lower than Tetric Flow. Admira Flow is filled $50 \%$ by volume, which is greater than Tetric Flow.

While the surface roughness difference between Tetric Flow and Esthet-X Flow was statistically different, the difference between Admira Flow and Esthet- $X$ flow was insignificant. This may


Figure 5. Interferometry microphotographs of representative samples of Tetric Flow. A. Under the mylar strip. B. Polished with diamond finishing burs, followed by finishing discs. C. Finished with only aluminum oxide discs. 

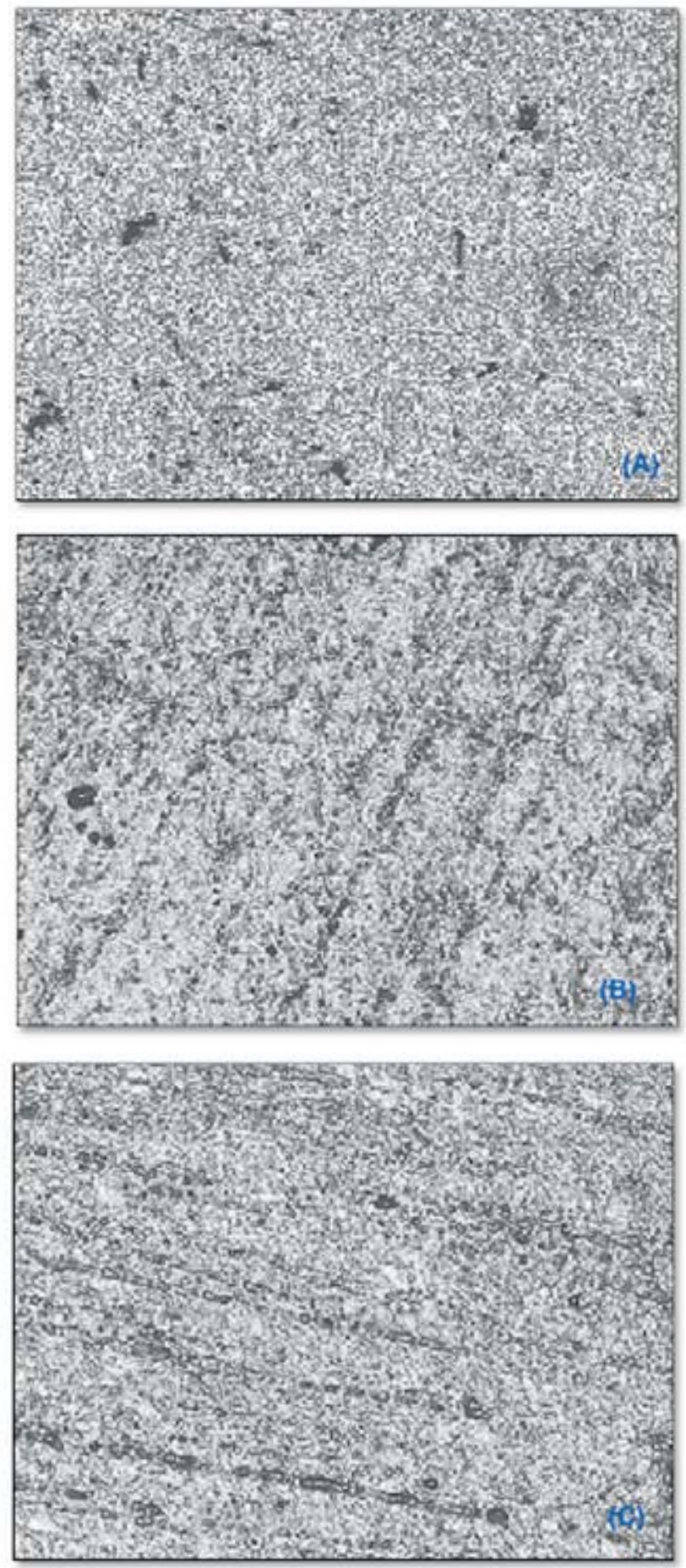

Figure 6. Interferometry microphotographs of representative samples of Esthet-X Flow. A. Under the mylar strip. B. Polished with diamond finishing burs, followed by finishing discs. C. Finished with only aluminum oxide discs.
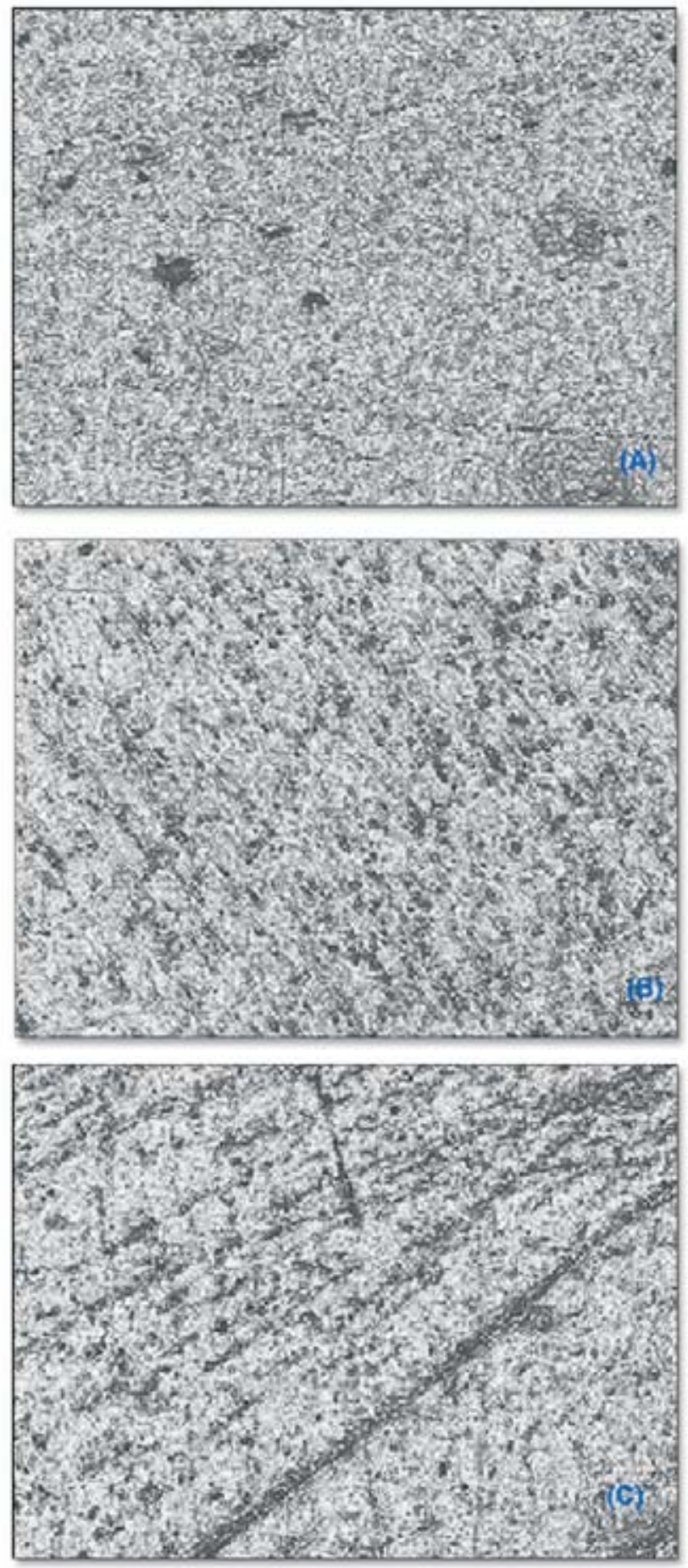

Figure 7. Interferometry microphotographs of representative samples of Dyract Flow. A. Under the mylar strip. B. Polished with diamond finishing burs, followed by finishing discs. C. Finished with only aluminum oxide discs. 

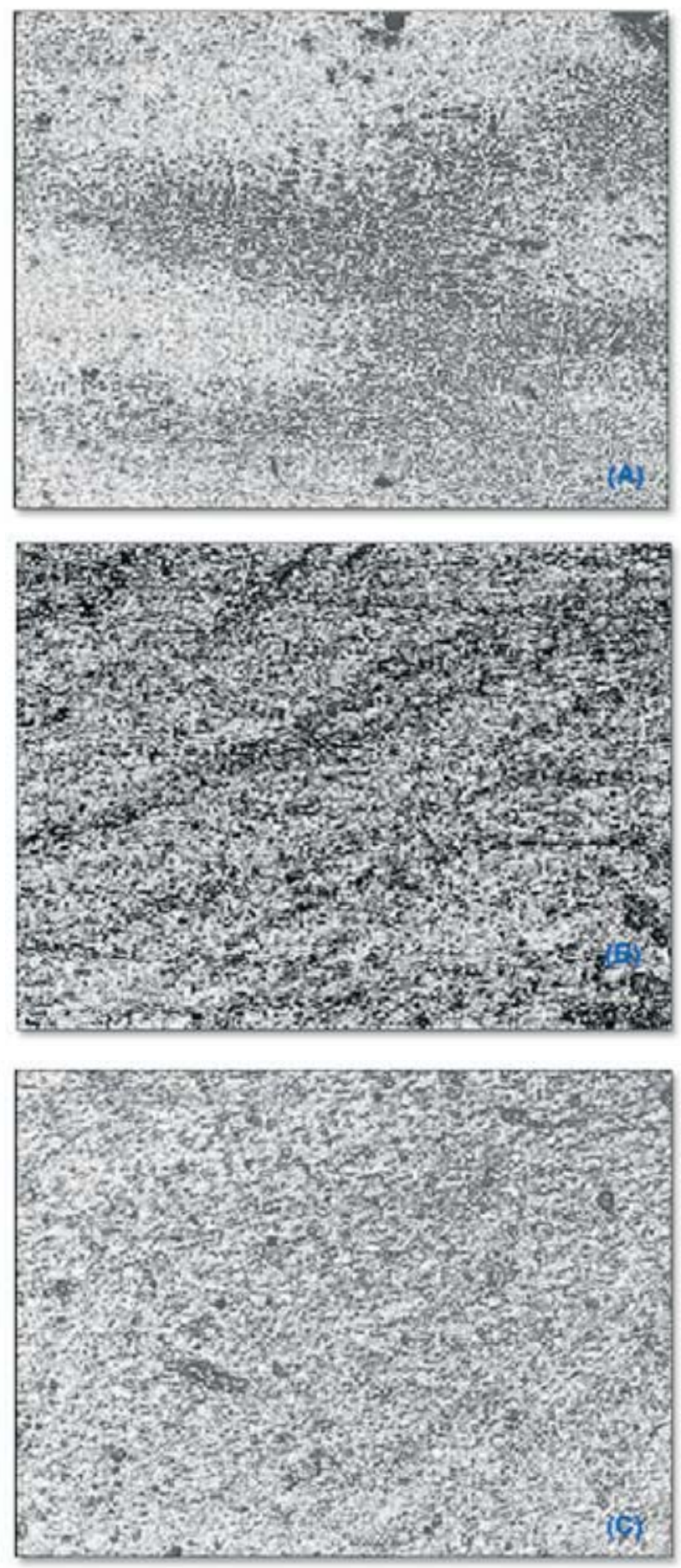

Figure 8. Interferometry microphotographs of representative samples of Admira Flow. A. Under the mylar strip. B. Polished with diamond finishing burs, followed by finishing discs. C. Finished with only aluminum oxide discs. hardness of restorative materials. ${ }^{24}$ Many different types of finishing and polishing techniques are available for tooth-colored restorative resins. ${ }^{15}$

In group II in the present study two different grits of diamond finishing burs were used initially to stimulate contouring or for removing excess material then followed by the use of a series of Sof-Lex Pop-on discs. As expected, the surface roughness of the Mylar formed surfaces for all flowable restorative resins was significantly increased by using finishing diamonds followed by discs as well as using just discs. This result corresponds with the findings of Üçtaşli et al. ${ }^{25}$ who observed statistically higher roughness values in flowable composites after finishing with Sof-Lex discs than those formed under a Mylar surface.

Jung et al. ${ }^{26}$ reported the possibility of wear to the sound tooth structure adjacent to restoration margins caused by using finishing diamonds. Moreover, it has been shown composite restorations not submitted to finishing procedures exhibit less wear in comparison to finished ones. ${ }^{27}$ Therefore, in group III the investigators of this study used only aluminum discs which has been a well documented procedure for finishing and polishing. ${ }^{28-30}$ It has been claimed once a bur is used on the surface, roughness increases and original smoothness cannot be regained regardless of the polishing system used. However, in the present study the surface roughness values in group II were not statistically different from the values obtained from group III except for Dyract Flow. In other words, aluminum discs overcame the rough surface created by finishing diamond burs. This result concurs with those of Özgünaltay et al. ${ }^{31}$ who evaluated various finishing/polishing procedures on the surface roughness of tooth-colored restoratives and found the use of carbide or diamond finishing burs followed by aluminum oxide discs provided the smoothest surface for all materials tested. They mentioned the ability of the discs to remove the surface scratches created by carbide or diamond burs. Interestingly, the Dyract Flow and Esthet-X Flow specimens treated initially with burs followed by discs showed some reduction in surface roughness as compared to just disc treatment alone. This might be due to the presence of glass particles in their composition. 


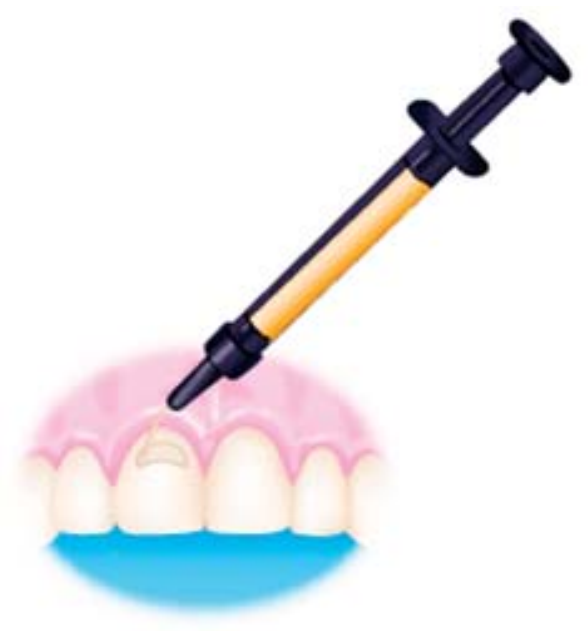

This difference is statistically significant only in Dyract Flow specimens because it is a compomer and has more glass fillers than Esthet-X Flow. Therefore, finishing burs are more effective for the mechanical removal of protruding glass fillers or they appear to be better suited for gross material reduction. Sof-Lex Pop-on polishing discs might be unable to flatten the glass filler particles. Conversely, in a study by Bouvier et al. ${ }^{32}$ the smoothest compomer surface was obtained using graded aluminum oxide discs. Another reason for high $\mathrm{Ra}$ values obtained with disc-treated Esthet-X Flow samples could be related to the resin components, which differ in the incorporation of BisEMA. BisEMA has a high molecular weight and fewer double-bonds resulting in a slightly softer matrix than other restoratives tested. ${ }^{12}$ Therefore, Sof-Lex discs abrade softer resin matrices at a higher rate and harder filler particles are left protruding from the surfaces, thus, providing rougher surfaces when compared with other disc-treated restoratives. However, the difference was statistically insignificant.
A critical threshold surface roughness value for bacteria adhesion is $0.2 \mu \mathrm{m} .{ }^{33}$ In the present study none of the tested materials subjected to either finishing/polishing procedure showed an $\mathrm{Ra}$ value above this limit.

Most studies have evaluated the surface characteristics of finishing and polishing instruments on different restorative materials using two dimensional models based on mechanical techniques. ${ }^{15-17,25,31}$ The primary disadvantage of a mechanical profilometer is the stylus that cannot penetrate certain irregularities. In the present study the Zygo 3-D surface profiler, based on scanning white light interferometry, was chosen to evalute surface roughness as it had already been used by Marigo et al. ${ }^{18}$ It provides non-contact, rapid, quantitative surface measurements. As a result, there is no deterioration of the sample. ${ }^{34}$ On the other hand, the Zygo 3-D profiler uses a beam of light that sweeps the sample surface more precisely detecting even tiny variations. ${ }^{34}$

\section{Conclusion}

Although the tested flowable restorative resins showed different surface roughness values under a Mylar strip, no differences were observed among the tested materials except for Dyract Flow when samples were finished with diamond burs followed by polishing discs and then compared to samples polished with discs only. In addition, the roughness did not differ between the two finishing/polishing methods used although they were rougher than baseline values. If it were possible to achieve a smooth surface without any excess, then finishing and polishing procedures could be eliminated. In such a scenario a flowable restorative resin with small filler particle size would be the restorative material of choice. 


\section{References}

1. Bayne SC, Thompson JY, Swift Jr, Stamatiades P, Wilkerson M. A characterization of flowable composites. J Am Dent Assoc. 1998; 129: 567-577.

2. Peutzfeldt A, Asmussen E. Composite restorations: Influence of flowable and self-curing resin composite linings on microleakage in vitro. Oper Dent. 2002; 27: 569-575.

3. Dunkin RT, Chambers DW. Gingival response to Class V composite resin restorations. J Am Dent Assoc. 1983; 106: 482-484.

4. Weitman RT, Eames WB. Plaque accumulation on composite surfaces after various finishing procedures. J Am Dent Assoc. 1975; 91: 101-106.

5. Yap AUJ, Sau CW, Lye KW. Effects of finishing/polishing time on surface characteristics of toothcoloured restoratives. J Oral Rehabil. 1998; 25: 456-61.

6. Dietschi D, Magne P, Holz J. Recent trends in esthetic restorations for posterior teeth. Quintessence Int. 1994; 25: 659-677.

7. Kaplan BA, Goldstein GR, Vijayaraghavan TV, Nelson IK. The effect of three polishing systems on the surface roughness of four hybrid composites: A profilometric and scanning electron microscopy study. J Prosthet Dent. 1996; 76: 34-8.

8. Hoelsher DC, Neme AML, Pink FE, Hughes PJ. The effect of three finishing systems on four aesthetic restorative materials. Oper Dent. 1998; 23: 36 -42.

9. Hondrum SO, Fernandez R. Contouring, finishing, and polishing class 5 restorative materials. Oper Dent. 1997; 22: 30 -36.

10. Pedrini D, Candido MSM, Rodrigues AL. Analysis of surface roughness of glass-ionomer cements and compomer. J Oral Rehabil. 2003; 30: 714-719.

11. Ferreira RS, Lopes GC, Baratieri LN. Direct posterior resin composite restorations: Considerations on finishing/polishing. Clinical procedures. Quintessence Int. 2004; 35: 359-366.

12. Ryba TM, Dunn WJ, Murchison DF. Surface roughness of various packable composites. Oper Dent. 2002; 27: 243-247.

13. Lu H, Roeder LB, Powers JM. Effect of polishing systems on the surface roughness of microhybrid composites. J Esthet Restor Dent. 2003; 15: 297-304.

14. Jung M, Voit S, Klimek J. Surface geometry of three packable and one hybrid composite after finishing. Oper Dent. 2003; 28: 53-59.

15. Baseren M. Surface roughness of nanofill and nanohybrid composite resin and ormocer-based tooth-colored restorative materials after several finishing and polishing procedures. J Biomater Appl. 2004; 19: 121-133.

16. Türkün LS, Tükrün M. The effect of one-step polishing system on the surface roughness of three esthetic resin composite materials. Oper Dent. 2004; 29: 203-211.

17. Yap AUJ, Yap SH, Teo CK, Ng JJ. Comparison of surface finish of new aesthetic restorative materials. Oper Dent. 2004; 29: 100-104.

18. Marigo L, Rizzi M, La Torre G, Rumi G. 3-D Surface Profile Analysis: Different finishing methods for resin composites. Oper Dent. 2001; 26: 562-568.

19. Roberson TM, Heymann HO, Swift EJ. Sturdevant's Art and Science of Operative Dentistry 4th edition St. Louis : Mosby; 2000: 194-196.

20. Chung K. Effects of finishing and polishing procedures on the surface texture of resin composites. Dent Mater. 1994; 10: 325-330.

21. Roeder LB, Tate WH, Powers JM. Effect of finishing and polishing procedures on the surface roughness of packable composites. Oper Dent. 2000, 25: 534-543.

22. Yap AUJ, Mok BYY. Surface finish of a new hybrid aesthetic restorative material. Oper Dent. 2002; 27: 161-166.

23. Setcos JC, Tarim B, Suzuki S. Surface finish produced on resin composites by new polishing systems. Quintessence Int. 1999; 30: 169-173.

24. Gordan VV, Patel SB, Barrett AA, Shen C. Effect of surface finishing and storage media on bi-axial flexure strength and microhardness of resin-based composite. Oper Dent. 2003; 28: 560-567.

25. Üçtaşli MB, Bala O, Güllü A. Surface roughness of flowable and packable composite resin materials after finishing with abrasive discs. J Oral Rehabil. 2004; 31: 1197-1202. 
26. Jung M. Surface roughness and cutting efficiency of composite finishing instruments. Oper Dent. 1997; 22: 98-104.

27. Ratanapridakul K, Leinfelder KF, Thomas JP. Effect of finishing on the in vivo wear rate of a posterior composite resin. J Am Dent Assoc. 1989; 118: 333-335.

28. Berastegui E, Canalda C, Brau E, Miguel C. Surface roughness of finished composite resins. J Prosthet Dent. 1992; 5: 742-749.

29. Toledano M, De La Torre FJ, Osorio R. Evaluation of two polishing methods for resin composites. Am J Dent. 1994; 7: 328-330.

30. Tate WH, Powers JM. Surface roughness of composites and hybrid ionomers. Oper Dent. 1996; 21: $53-58$

31. Özgünaltay G, Yazici AR, Görücü J. Effect of finishing and polishing procedures on the surface roughness of new tooth-colored restoratives. J Oral Rehabil. 2003; 30: 218-224.

32. Bouvier D, Duprez JP, Lissac M. Comparative evaluation of polishing systems on the surface of three aesthetic materials. J Oral Rehabil. 1997; 24: 888-894.

33. Bollen CML, Lambrechts $P$, Quirynen M. Comparison of surface roughness of oral hard materials to the threshold surface roughness for bacterial plaque retention: A review of the literature. Dent Mater. 1997; 13: 258-269.

34. Joniot SB, Gregoire GL, Auther AM, Roques YM. Three-Dimensional optical profilometry analysis of surface states obtained after finishing sequences for three composite resins. Oper Dent. 2000; 25: 311-315.

\section{About the Authors}
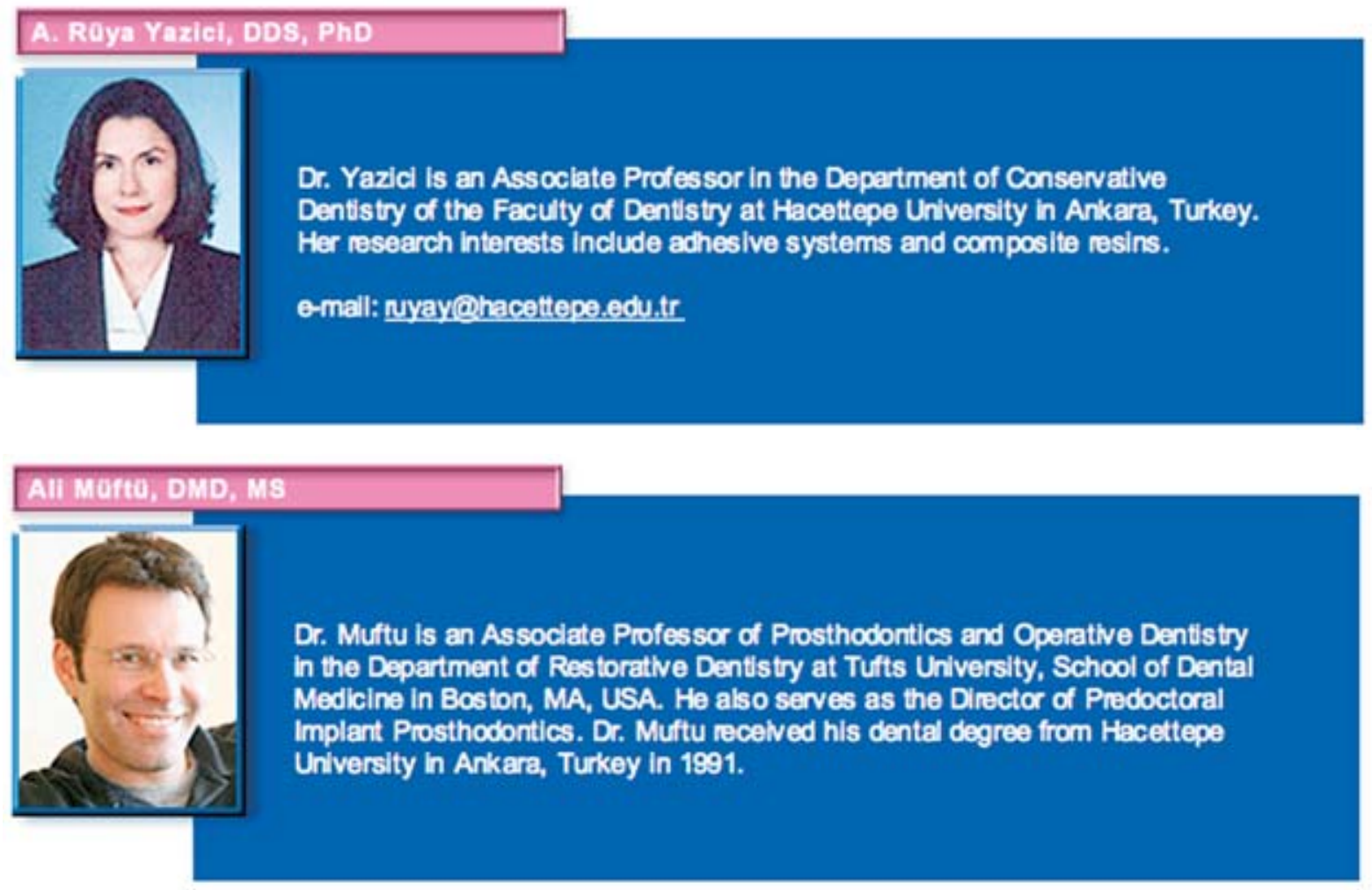


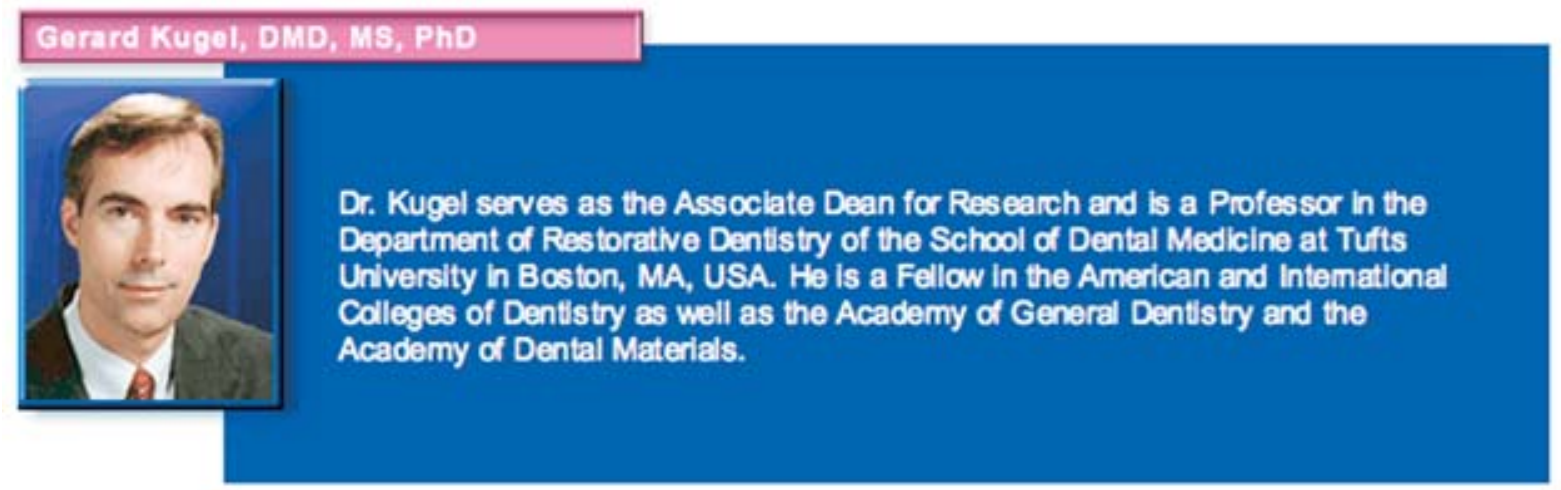

\section{Acknowledgements}

The authors gratefully acknowledge the Zygo Corporation for the invaluable assistance with this project and thank Mr. Manas Lakshmipathy for his technical assistance with the operation of the Zygo optical profiler. 